\title{
PENERAPAN INTERNET OF THINGS ( IoT ) DALAM PEMBELAJARAN DI UNISNU JEPARA
}

\author{
Dias Prihatmoko \\ Program Studi Teknik Elektro \\ UNISNU Jepara \\ Email: diasprihatmoko@gmail.com
}

\begin{abstract}
ABSTRAK
Di era globalisasi saat ini, perkembangan ilmu pengetahuan dan teknologi sangat pesat, khususnya yaitu perkembangan internet. Oleh karena itu dunia pendidikan pun tidak lepas dari perkembangan internet. Untuk itu dalam pembelajaran perlu adanya media belajar yaitu internet. Dengan berkembangnya Internet of Things (IoT), maka internet pun bisa dimanfaatkan untuk keperluan lain yang mendukung pembelajaran, diantaranya yaitu dengan memanfaatkan internet tersebut untuk kegiatan pembelajaran teori maupun praktikum. Salah satu contohnya yaitu pemanfaatan internet untuk kegiatan pembelajaran mata kuliah mikrokontroller yang diterapkan di program studi Teknik Elektro UNISNU Jepara. Internet tersebut digunakan sebagai sarana untuk sistem kontrol otomatis dengan jarak jauh menggunakan mikrokontroller. Penerapan dari internet of things (IoT) di teknik elektro UNISNU Jepara adalah berupa pengendalian perangkat elektronik berupa lampu LED menggunakan mikrokontroller arduino uno dengan memanfaatkan internet. Penerapan berupa tugas sistem kontrol lampu yang dirancang menggunakan perangkat keras ( lampu led dan pin arduino ), serta menggunakan perangkat lunak berupa bahasa pemrograman PHP, pemrograman Batch, dan pemrograman Arduino. Hasil dari perancangan adalah sistem kontrol lampu LED yang dapat dikendalikan melalui internet. Sedangkan hasil dari pengamatan proses pembelajaran adalah tingkat ketertarikan mahasiswa sesudah pembelajaran sebesar 90 $\%$ mahasiswa tertarik mengikuti proses pembelajaran dan $50 \%$ mahasiswa paham dengan apa yang disampaikan dosen pada saat pembelajaran.
\end{abstract}

Kata kunci: internet of things, sistem control, mikrokontroller.

\begin{abstract}
In the era of globalization, The internet technology is developed very rapidly over the world. Consequently the IT could be applied to support learning, including by making use of the internet for theoretical and practical learning activites. One example is the use of the internet for learning activites. Mikrokontroller applied subjects in the program study electrical engineering. The internet is used as a means for automated control system by remotely using a mikrokontroller. Implementation of the internet of things (IOT) in electrical engineering course UNISNU Jepara is a form of control of electronic devices such as LED lights using mikrokontroller arduino uno by utilizing the internet. Implementation of such a task light control system that is designed to use the hardware (the LED lights and pin arduino), as well as using software such as PHP programming language, programming Batch, and Arduino programming. The result of the design is the LED light control system that can be controlled via the Internet. Data from semester evaluation showed that more than $90 \%$ student interested to study the subject and $50 \%$ of student have good understanding.
\end{abstract}

Keywords: internet of things, mikrokontroller, control system.

\section{PENDAHULUAN}

\subsection{Latar Belakang}

Di era globalisasi saat ini, perkembangan ilmu pengetahuan dan teknologi sangat pesat, khususnya yaitu perkembangan internet. Oleh karena itu dunia pendidikan pun tidak lepas dari perkembangan internet. Untuk itu dalam pembelajaran perlu adanya media belajar yaitu internet. Dengan adanya media tersebut setiap mahasiswa mampu memanfaatkan internet sesuai dengan kebutuhan pendidikan. Di samping itu pemanfaatan internet sebagai media belajar sangat memudahkan mahasiswa dalam mengakses informasi tentang ilmu pengetahuan, mengirim tugas-tugas lewat email, dan lain sebagainya 
[1]. Selain mahasiswa, dosen juga dapat mempermudah dalam menyampaikan pembelajaran. Pemanfaatan media internet sangat penting untuk terlaksananya pembelajaran yang baik.

Dengan berkembangnya Internet of Things (IoT), maka internet pun bisa dimanfaatkan untuk keperluan lain yang mendukung pembelajaran [2], diantaranya yaitu dengan memanfaatkan internet tersebut untuk kegiatan pembelajaran teori maupun praktikum. Salah satu contohnya yaitu pemanfaatan internet untuk kegiatan pembelajaran mata kuliah mikrokontroller yang diterapkan di program studi Teknik Elektro UNISNU Jepara. Internet tersebut digunakan sebagai sarana untuk sistem kontrol otomatis dengan jarak jauh menggunakan mikrokontroller.

Mata kuliah mikrokontroller dibagi menjadi 2 bagian yaitu mata kuliah teori mikrokontroller dan mata kuliah praktikum. Pada mata kuliah teori mahasiswa diajarkan tentang beberapa teori tentang ilmu mikrokontroller, diantaranya membahas tentang arsitektur sistem mikrokontroller, dasar pemrograman mikrokontroller, timer, counter, interupsi, dan aplikasi pemrograman mikrokontroller. Di akhir mata kuliah ini mahasiswa sudah dapat memahami dan memprogram mikrokontroller. Mikrokontroller yang digunakan adalah Arduino Uno Rev 3. Setelah mata kuliah teori maka disambung pada semester berikutnya dengan mata kuliah praktikum, dalam mata kuliah praktikum tersebut dilakukan pendalaman lagi tentang aplikasi mikrokontroller. Di akhir mata kuliah ada tugas kelompok tentang proyek aplikasi pemrograman mikrokontroller. Salah satunya yaitu sistem kontrol aktuator dengan memanfaatkan internet yang termasuk dalam kelompok ilmu Internet of Things. Oleh karena itu internet of things telah diterapkan dalam pembelajaran di Program Studi Teknik Elektro UNISNU Jepara.

\subsection{Rumusan Masalah}

Rumusan masalah dalam penelitian ini adalah sebagai berikut :

1) Bagaimana merancang sistem kontrol lampu LED dengan memanfaatkan internet ?

2) Bagaimana penerapan sistem dalam pembelajaran di UNISNU Jepara?

3) Bagaiman hasil pengujian dari rancangan prototype sistem kontrol yang dibuat?

\section{METODOLOGI}

Bagian dibawah ini menjelaskan tentang langkah penelitian beserta alat dan bahan yang di gunakan dalam penelitian:

a. Langkah-langkah Penelitian

Langkah penelitian ditunjukkan pada gambar 1 dibawah ini :

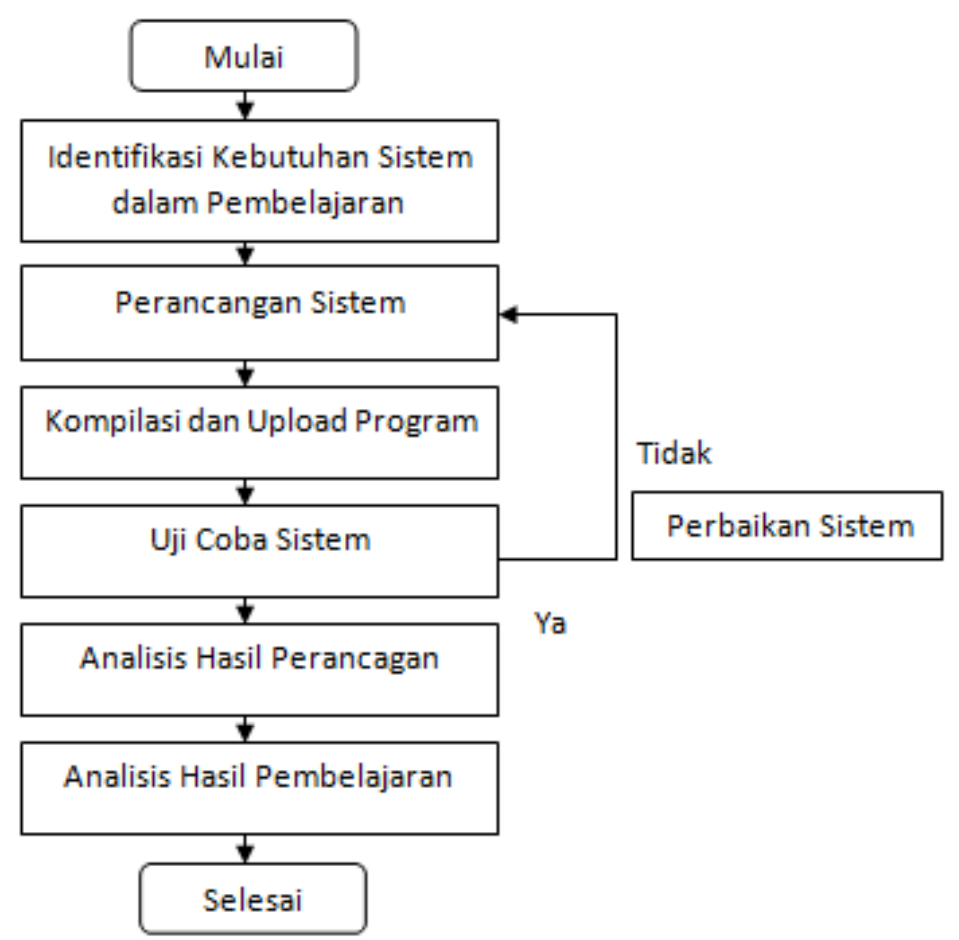

Gambar 1. Diagram Alir Langkah-Langkah Penelitian 
Langkah-langkah yang dilakukan dalam penelitian ini yang pertama adalah Identifikasi kebutuhan sistem dalam hal ini merupakan proses pengidentifikasian yang akan diselesaikan dan diteliti di penelitian ini. Kemudian dilakukan Perancangan sistem berdasarkan pengkajian serta ujicoba yang dilakukan terhadap semua teori serta metode yang berhubungan dengan topik penelitian ini. Kajian tersebut terkait dengan: (1) arsitektur system mikrokontroller, (2) perancangan sistem Internet of Things (3) pembuatan program, dan (4) peralatan yang digunakan dalam perancangan. Setelah semua pilihan tersebut ditentukan, maka dilakukan kompilasi dan upload program.

Langkah selanjutnya adalah uji coba perancangan sistem untuk memastikan bahwa perancangan sistem bisa diterapkan secara real yaitu diaplikasikan di rangkaian perangkat keras mikrokontroller dan bisa berjalan dengan baik. Langkah selanjutnya adalah pengujian, pengujian ini dilakukan terhadap bagian-bagian penting dari sistem. Bagian-bagian penting tersebut antara lain: (1) Sistem kontrol berbabis IoT (2) Pengujian penerapan tingkat ketertarikan dan tingkat pemahaman dalam pembelajaran. Pengujian dilakukan hingga dicapai hasil terbaik berdasarkan pengujian dan analisis. Pengujian dan analisis sistem menghasilkan sistem yang lebih baik secara keseluruhan. Kemudian dari hasil tersebut dibuat laporan penelitian.

b. Alat dan Bahan

Alat dan bahan yang digunakan dalam penelitian penerapan IoT dalam pembelajaran di UNISNU Jepara adalah :

1) Arduino

2) Resistor

3) Lampu LED

Sedangkan perangkat lunak yang digunakan dalam terdiri dari:

1) Notepad++

2) Sketch Arduino

\section{c. Alur Kerja Sistem}

Perancangan sistem pengontrol lampu berbasis mikrokontroller arduino uno menggunakan sistem satu arah. Diawali dengan identifikasi permasalahan, kemudian dilakukan perancangan sistem dengan melakukan berbagai kajian tentang arsitektur dan perancangan, kemudian dilakukan kompilasi dan upload program. Jika rangkaian sudah diaplikasikan ke perangkat keras arduino, hal selanjutnya adalah melakukan pengujian untuk mendapatkan hasil serta dianalisa, dan akhirnya dibuat laporan penelitian.

d. Penerapan Internet of Things berbasis web menggunakan Arduino

Berikut adalah rangkaian mikrokontroller arduino uno dengan tiga buah lampu LED yang dirangkai dan diaplikasikan pada pembelajaran di UNISNU Jepara.

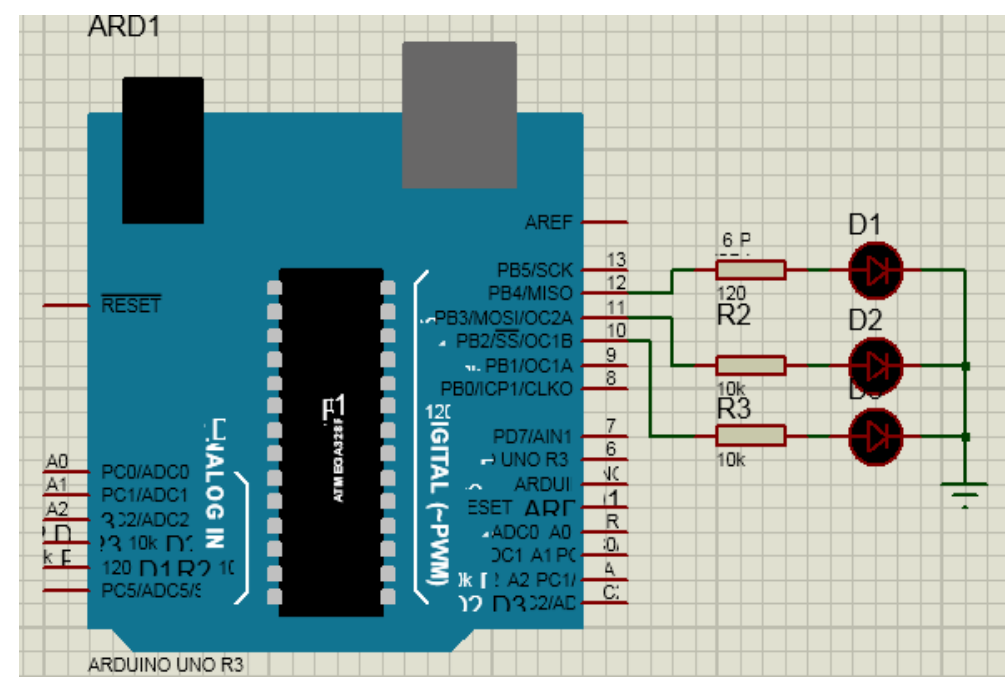

Gambar 2. Skema Rangkaian Kontrol Lampu LED

Internet of Things ( IoT ) adalah arsitektur sistem yang terdiri dari perangkat keras, perangkat lunak, dan Web, Karena perbedaan protokol antara perangkat keras dengan protokol web, maka di perlukan sistem embedded berupa gateway untuk menghubungkan dan 
menjembatani perbedan protokol tersebut. Perangkat bisa terhubung ke internet menggunakan beberapa cara seperti Ethernet, WIFI, dan lain sebagainya. perangkat mungkin juga tidak terkoneksi dengan internet secara langsung, akan tetapi dibentuk kluster-kluster dan terhubung ke koordinator.

Pada salah satu percobaan tersebut diatas dilakukan kendali lampu LED yang diakses melalui web browser. Skema rangkaian digambarkan pada gambar 1 yang memperlihatkan Arduino uno pin 12, pin 11, dan pin 10 yang berupa pin digital output yang terhubung dengan lampu LED dan resistor.

Dalam membuat kendali lampu LED tersebut, langkah kerjanya adalah sebagai berikut:

1) Perangkat keras yang digunakan yaitu Arduino Uno Rev 3 dan Komputer untuk memprogram dan mengakses arduino melalui browser

2) Membuat rangkaian sesuai dengan skema rangkaian pada gambar 1

3) Mengkonfigurasi USB to Serial, dan SPI untuk komunikasi dan pemrograman arduino

4) Menginstall web server di komputer yang akan merespon request dari client.

5) Mengkompilasi program dan upload ke Arduino Uno Rev 3.

6) Mengujicoba rangkaian yang terhubung ke komputer menggunakan web browser

\section{HASIL DAN PEMBAHASAN}

\subsection{Hasil}

Hasil Uji coba dibagi menjadi 2 tahap yaitu uji coba sistem berbasis internet of things dan uji coba penerapan internet of things dalam pembelajaran, pengujian tersebut dimaksudkan untuk melihat kerja dari mikrokontroler ataupun software yang sudah diprogram sudah sesuai dengan yang dirancang dan penerapannya dalam pembelajaran di UNISNU Jepara.

\subsubsection{Sistem Kontrol Lampu Led Menggunakan Internet}

a. Perangkat Keras

Berikut menjelaskan tentang hasil perangkat keras yang sudah dibuat. Hasil tersebut ditunjukkan pada gambar dibawah ini.

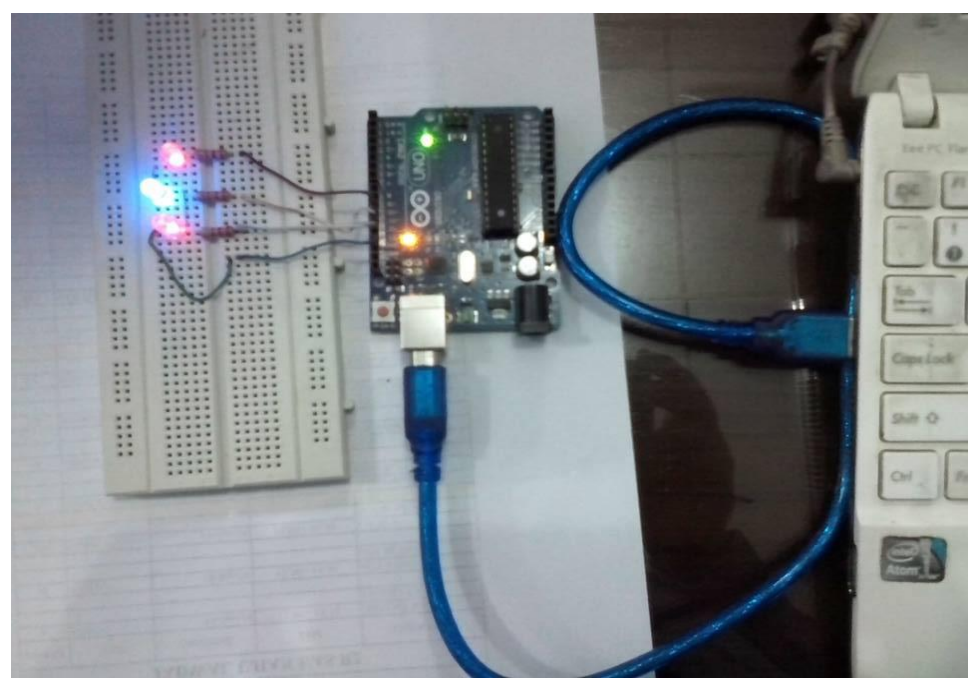

Gambar 3. Tampilan Perangkat Keras

Komponen penyusun rangkaian perangkat keras sistem kontrol lampu LED menggunakan internet ada 3 macam, yaitu 1 buah arduino sebagai komponen utama, 3 buah resistor dan 3 buah lampu LED. Lampu tersebut di kontrol melalui halaman web, bisa menggunakan komputer atau juga handphone. Lampu LED 1 dihubungkan ke pin digital 12 arduino, LED 2 dihubungkan ke pin digital 11 arduino dan LED 3 dihubungkan ke pin digital 10. Lampu akan menyala secara otomatis jika tombol button di halaman web di klik. 
b. Perangkat Lunak

Berikut adalah tampilan halaman web untuk digunakan sebagai antar muka untuk menghidupkan dan mematikan lampu LED menggunakan web.

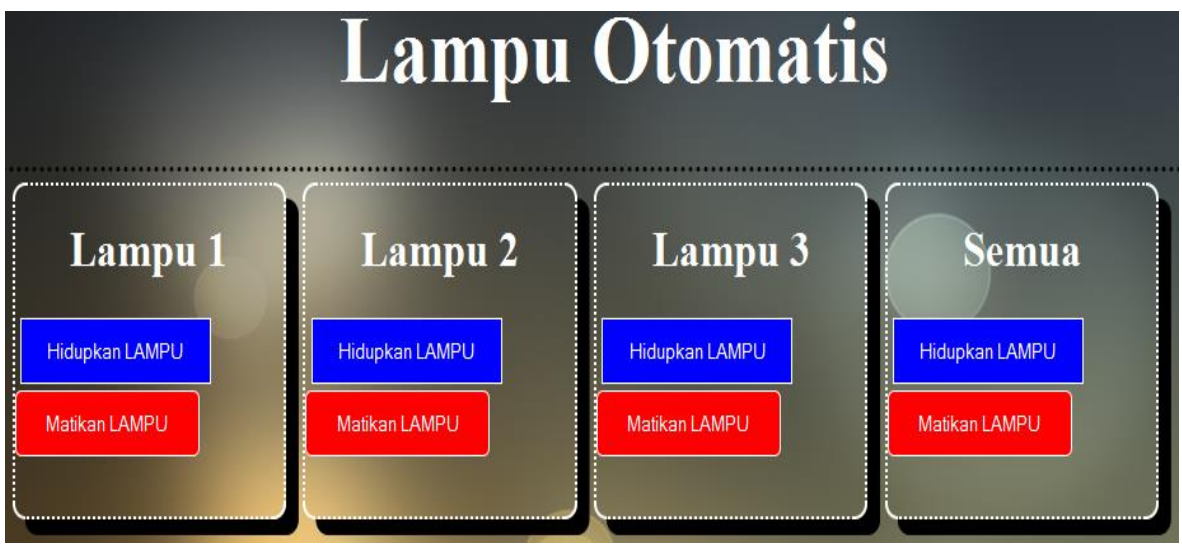

Gambar 4. Tampilan Halaman Web

Perangkat lunak yang digunakan adalah berupa perangkat lunak berbasis web yang digunakan untuk antar muka sistem dan file batch yang berfungsi untuk memerintah dan menjalankan suatu program, file ini berupa file extention.bat. Prinsip kerja dari halaman web tersebut adalah dengan meng-klik tombol pada masing-masing button maka lampu akan menyala, jika button 'Hidupkan LAMPU 1' di klik maka secara otomatis akan memanggil file batch ON1.bat, file batch tersebut akan memanggil program arduino ON1.cpp.hex untuk di upload ke arduino dan akan menghidupkan lampu 1. Untuk mematikan lampu, jika button 'Matikan LAMPU 1' di klik maka secara otomatis akan memanggil file batch OFF1.bat, file batch tersebut akan memanggil program arduino OFF1.cpp.hex untuk di upload ke arduino dan akan mematikan lampu 1. Hal yang sama akan berlaku untuk lampu 2, lampu 3, dan semua lampu.

\subsubsection{Pengujian Penerapan Internet of Things dalam Pembelajaran}

Pengujian penerapan Internet of Things dalam pembelajaran di UNISNU Jepara dibagi dalam dua hal yaitu, (1). Pengujian tingkat ketertarikan mahasiswa dan (2). Pengujian tingkat pemahaman mahasiswa. Pengujian tersebut menggunakan kuesioner yang diisi oleh mahasiswa dan juga wawancara dosen terhadap mahasiswa. Berikut adalah tabel hasil pengujian tentang tingkat ketertarikan mahasiswa terhadap mata kuliah mikrokontroller.

Tabel 1. Pengujiaan tingkat ketertarikan mahasiswa

\begin{tabular}{ccccc}
\hline No & Mahasiswa & $\begin{array}{c}\text { Ketertarikan } \\
\text { Sebelum } \\
\text { Perkuliahan }\end{array}$ & $\begin{array}{c}\text { Keberhasilan } \\
\text { Mengerjakan } \\
\text { Tugas }\end{array}$ & $\begin{array}{c}\text { Ketertarikan } \\
\text { Setelah } \\
\text { Perkuliahan }\end{array}$ \\
\hline 1 & Mahasiswa 1 & Tertarik & Berhasil & Tertarik \\
2 & Mahasiswa 2 & Tidak Tertarik & Tidak Berhasil & Tertarik \\
3 & Mahasiswa 3 & Tertarik & Berhasil & Tertarik \\
4 & Mahasiswa 4 & Tertarik & Berhasil & Tertarik \\
5 & Mahasiswa 5 & Tertarik & Berhasil & Tertarik \\
6 & Mahasiswa 6 & Tidak Tertarik & Tidak Berhasil & Tidak Tertarik \\
7 & Mahasiswa 7 & Tertarik & Berhasil & Tertarik \\
8 & Mahasiswa 8 & Tertarik & Berhasil & Tertarik \\
9 & Mahasiswa 9 & Tidak Tertarik & Berhasil & Tertarik \\
10 & Mahasiswa 10 & Tertarik & Berhasil & Tertarik \\
\hline
\end{tabular}

Pengujian tingkat ketertarikan mahasiswa ini dilakukan selama satu semester, yaitu dimulai dari sebelum perkuliahan sampai dengan sesudah perkuliahan. Hal ini dilakukan untuk tujuan mengetahui tingkat ketertarikan mahasiswa dalam mempelajari mikrokontroller. Pengujian dilakukan terhadap 10 kelompok mahasiswa, pada saat sebelum perkuliahan tepatnya adalah saat pertama kali perkuliahan, mahasiswa dikumpulkan dan diberi pengarahan tentang mikrokontroller terkait dengan pengenalan dasar 
dan penggunaan dasar mikrokontroller tersebut. Dari hasil pengujian diatas didapat bahwa $70 \%$ mahasiswa tertarik dengan perkuliahan mikrokontroller sedangkan $30 \%$ mahasiswa kurang tertarik dengan perkuliahan mikrokontroller. Untuk tingkat keberhasilan mahasiswa dalam mengerjakan tugas mikrokontroller yaitu kontrol lampu led menggunakan internet didapat sebanyak $80 \%$ mahasiswa berhasil mengerjakan tugas dan sebanyak $20 \%$ mahasiswa belum berhasil dalam mengerjakan tugas. Sedangkan untuk tingkat ketertarikan mahasiswa setelah perkuliahan sebanyak $90 \%$ mahasiswa tertarik dalam mengikuti perkuliahan dan sebanyak $10 \%$ mahasiswa kurang tertarik dalam mengikuti perkuliahan tersebut. Dari beberapa hal diatas tingkat ketertarikan dapat mempengaruhi tingkat keberhasilan mahasiswa dan juga sebaliknya bahwa tingkat keberhasilan dapat mempengaruhi ketertarikan mahasiswa walaupun awalnya mahasiswa tersebut kurang tertarik.

Tabel 2. Pengujiaan tingkat pemahaman mahasiswa

\begin{tabular}{|c|c|c|}
\hline No & Kriteria Penilaian & Nilai \\
\hline & Perakitan Perangkat Keras & \\
\hline 1 & Perakitan Komponen Lampu LED & 4,6 \\
\hline \multirow[t]{2}{*}{2} & Pemakaian PIN I/O Arduino & 4,4 \\
\hline & Penguasaan Software IDE Arduino & \\
\hline 3 & Menjalankan Software IDE & 4,5 \\
\hline \multirow[t]{2}{*}{4} & Penggunaan Tool IDE & 4 \\
\hline & Penguasaan Pemrograman Arduino & \\
\hline 5 & Lampu LED Menyala & 4,2 \\
\hline 6 & Lampu LED Padam & 4,2 \\
\hline \multirow[t]{2}{*}{7} & Lampu LED Berkedip & 4,4 \\
\hline & Penguasaan File Batch & \\
\hline \multirow[t]{2}{*}{8} & Pemrograman File Batch & 3,6 \\
\hline & Pemrograman Halaman Antar Muka & \\
\hline 9 & Pemrograman Halaman Web Sederhana & 4 \\
\hline 10 & Menginstal Web Server Sederhana & 4,2 \\
\hline 11 & Konfigurasi Port Serial & 3,9 \\
\hline
\end{tabular}

Pada tabel 2 diatas menjelaskan tentang pengujian tingkat pemahaman mahasiswa dalam mengikuti perkuliahan pada mata kuliah mikrokontroller. Pengujian dilakukan dengan menggunakan wawancara tugas pada saat mahasiswa melakukan presentasi tugas. Terdapat lima buah kriteria penilaian dengan rentang nilai antara 1 sampai dengan 5. (1). Sangat kurang paham, (2). Kurang paham, (3). Cukup Paham, (4). Paham, (5). Sangat paham. Sedangkan untuk kriteria penilaian ada 5 kriteria diantaranya yaitu : (1). Penilaian tentang perakitan perangkat keras yang terdiri dari perakitan komponen lampu LED dan pemakaian pin I/O arduino, (2). Penilaian tentang penguasaan software IDE Arduino yang terdiri dari penguasaan dalam menjalankan software IDE Arduino dan penguasaan penggunaan tool software IDE arduino, (3). Penilaian tentang penguasaan pemrograman arduino yang terdiri dari penguasaan menyalakan, mematikan dan LED berkedip, (4). Penilaian tentang penguasaan pemrograman file batch, dan (5). Penilaian tentang penguasaan pemrograman halaman antar muka, yang terdiri dari pemrograman halaman web sederhana, menginstal web server sederhana serta mengkonfigurasi port serial.

Dari rekap kuesioner penilaian tingkat pemahaman mahasiswa didapat bahwa kriteria penilaian tentang materi ('perakitan komponen lampu LED') sebesar 4,6. Pemakaian pin I/O arduino sebesar 4,4. Menjalankan Software IDE sebesar 4,5. Penggunaan Tool IDE sebesar 4,0. Penguasaan Lampu LED Menyala sebesar 4,2. Lampu LED Padam sebesar 4,2. Lampu LED Berkedip sebesar 4,4. Penguasaan pemrograman file Batch sebesar 3,6. Pemrograman halaman web sederhana sebesar 4,0. Penguasaan instalasi web server sederhana sebesar 4,2 dan konfigurasi port serial sebesar 3,9. Dari hasil tersebut didapat nilai diatas 3,0 hal ini berarti bahwa tingkat pemahaman mahasiswa berada dalam kategori diatas 'Cukup' dan jika dirata-rata yaitu hasilnya sebesar 4,0. Ini berarti bahwa rata-rata sebagian besar mahasiswa dapat memahami materi tentang mikrokontroller. 


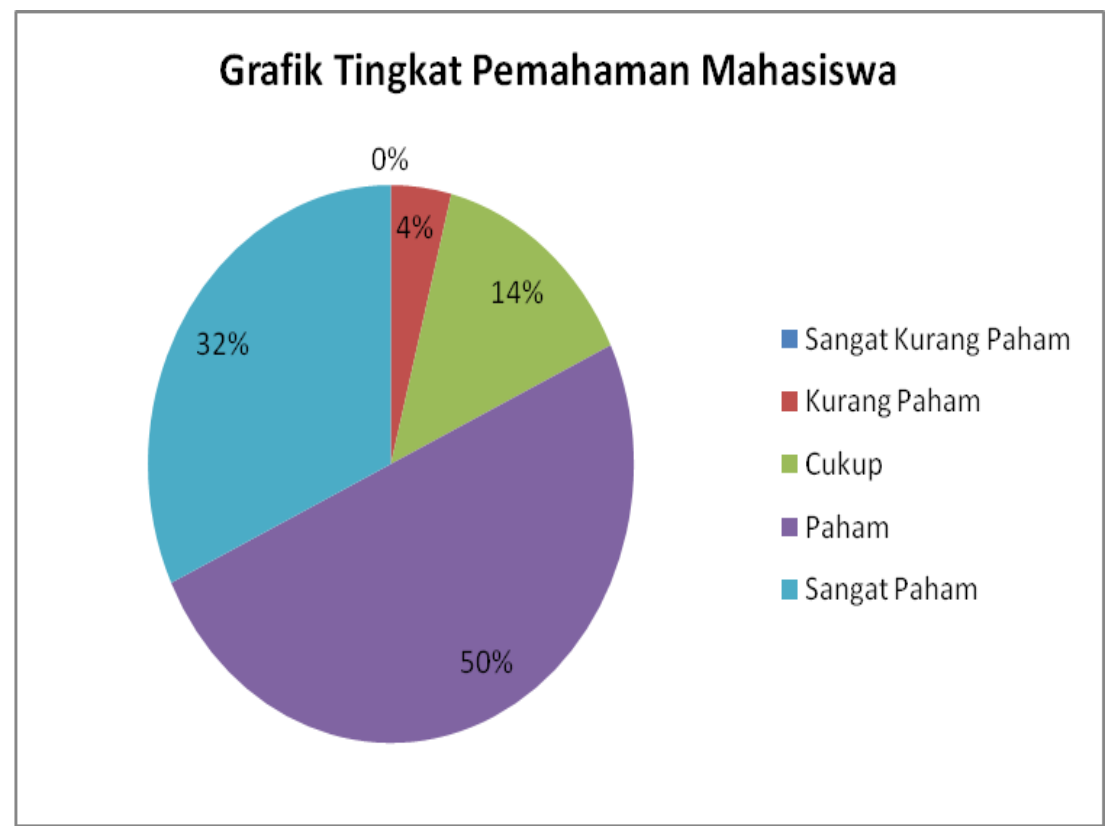

Gambar 5. Grafik Tingkat Pemahaman Mahasiswa

Sedangkan jika hasil kuesioner tersebut di buat prosentase didapat bahwa prosentase tingkat pemahaman masing - masing mahasiswa berbeda-beda, hasil dari kuesioner setelah diolah didapat bahwa sebanyak $32 \%$ mahasiswa sangat paham, $50 \%$ mahasiswa paham, $14 \%$ mahasiswa cukup paham, dan 4 $\%$ mahasiswa kurang paham. Dari grafik tersebut dapat disimpulkan bahwa materi tentang mikrokontroller yang telah disampaikan pada semester tersebut dapat dipahami oleh lebih dari $80 \%$ mahasiswa.

\section{KESIMPULAN} berikut:

Dari penelitian yang telah dilakukan, terdapat beberapa kesimpulan antara lain adalah sebagai

a. Penelitian menghasilkan Sistem Kontrol Lampu LED yang dapat digunakan untuk mengontrol lampu LED secara otomatis menggunakan web.

b. Internet of Things (IoT) telah diterapkan pada pembelajaran di teknik elektro UNISNU Jepara.

c. Perancangan Dan Implementasi Sistem Kontrol lampu LED menggunakan mikrokontroller Arduino Uno dan web layak digunakan dan diaplikasikan sebagai sistem kontrol lampu LED.

d. Hasil dari proses pembelajaran mata kuliah mikrokontroller lebih dari $80 \%$ mahasiswa paham dan bisa membuat program mikrokontroller dengan baik.

e. Ketertarikan mahasiswa dalam pembelajaran dapat mempengaruhi keberhasilan dalam mengerjakan tugas.

\section{DAFTAR PUSTAKA}

[1] Dias P, dkk, (2013). Pengembangan Perangkat Lunak Gateway untuk Home Automation Berbasis IQRF TR53B Menggunakan Konsep CGI, SESINDO 2013, Bali. Desember 2013.

[2] Endi Sailul Haq, dkk, (2014). Trainer Mikrokontroller Sebagai Media Pembelajaran Untuk Meningkatkan Kompetensi Siswa di SMK Nnegeri Banyuwangi. Jurnal Seminar nasional Teknologi Informasi dan Mulimedia. STIMIK AMIKOM Yogyakarta. Februari 2014.

[3] Feri Sasaha Nurahmad, (2012). Upaya Meningkatkan Kompetensi Siswa Pada Mata Pelajaran Sistem Mikrokontroller dengan Metode Kooperatif di SMK Negeri 2 Pengasih, Skripsi. UNY Yogyakarta

[4] Sulhan Setiawan. (2009). Mudah dan Menyenangkan Belajar Mikrokontreoller. ANDI. Yogyakarta.

[5] Lutfi HK, dkk (2013). Rancang Bangun Pengendali Lampu Ruangan Menggunakan Remote Control dan Real Time Clock Berbasis ATMega8535. Program studi DIII sekolah Tinggi Teknologi Telematika Telkom Purwokerto.

[6] Raka yusuf, pemrograman berbasis web 2, pusat pengembangan bahan ajar-UM 
[7] Web server dan aplikasinya, (2012). Di akses 15 maret 2013, dari website: http://hadisimpl3.blogspot.com/2012/10/web-server-aplikasinya.html

[8] Eko Budi Setiawan. pengenalan bahasa C, diktat mata kuliah pemrograman I, UNIKOM, 2011

[9] Abdusy Syarif, Sistem Operasi, pusat pengembangan bahan ajar, Universitas Mercu Buana, 2011

[10] Enjang A Juanda, (2011). Media Pembelajaran Berbasis Multimedia Interaktif Untuk Meningkatkan Pemahaman Dasar-Dasar Mikrokontroller. Jurnal Ilmu Pendidikan Jilid 17 No 6, tahun 2011. Bandung.

[11] Umi Rochayati, dkk, (2012). Inovasi Media Pembelajaran Sain Teknologi di SMP Berbasis Mikrokontroller. Jurnal Kependidikan Vol 42 Nomor 1 Tahun 2012 halaman 89 - 98. Yogyakarta. 